\title{
Best Article Award: Kim, An and Kim
}

\author{
Katherine S. Virgo ${ }^{1}$
}

Published online: 7 January 2017

(C) International Atlantic Economic Society 2017

The Atlantic Economic Journal is proud to announce that the winners of the 2016 Best Article Award are Gil Kim, California State University-Fresno, Lian An, University of North Florida, and Yoonbai Kim, University of Kentucky. Their paper entitled, "Exchange Rate, Capital Flows, and Output: Developed versus Developing Economies," appeared in the June 2015 issue of the AEJ. The AEJ Best Article Award committee reviewed all eligible papers (those with ratings of top 25 percent or better) published in 2015. The committee was chaired by IAES Vice President, Barry Eichengreen, George C. Pardee and Helen N. Pardee Professor of Economics and Political Science, University of California-Berkeley. Members of the committee included the AEJ Board of Editors and IAES Endowment Fund sponsors. The Managing Editor gratefully acknowledges the participation and diligence of all committee members who participated in the review process. The award emphasizes the intellectual and scholarly approach to economic research which has always been a focal point of the AEJ.

In their review of the literature, the authors identify conflicting points of view with respect to the impact of currency devaluations on output. Similarly, they report that consensus is lacking on the issue of whether capital flows benefit growth. The Kim et al. paper (2015) contributes to the literature by simultaneously examining the influence of both exchange rate movements and capital flows on output in a single unifying model, while controlling for other shocks. The authors employ a vector autoregression (VAR) model with Cholesky decomposition to analyze 13 relatively small open economies; six developed (Canada, Switzerland, Australia, Italy, the Netherlands, and Spain) and seven developing (Mexico, Indonesia, Korea, Malaysia, Philippines, Brazil, and Chile). The sample period ranges from almost 15 years for Chile (1996:12010:3) to slightly over 40 years for Switzerland (1970:1-2010:3). Though responses to exchange rate and capital flow shocks were diverse and country-specific, the authors detect some common results within developing and developed countries.

Katherine S. Virgo

kvirgo@emory.edu

1 Emory University, Atlanta, GA 30322, USA 
First, their findings indicate that the likelihood of contractionary devaluation is higher in developing countries, while expansionary devaluation is more common in developed countries. Kim et al. (2014) suggest that developing countries can be subject to an inability to borrow abroad in their own currencies (termed "original sin"). In addition, devaluation may cause developing countries to lose access to international capital markets and accelerate capital outflow. By contrast, since developed countries are not subject to original sin, output is generally expansionary in response to currency depreciation.

Second, in developing countries facing currency depreciation, the current account tends to improve. After depreciation, however, positive improvements in the current account have little impact on whether output improves. According to the authors, this is possible if the observed improvements in the current account are achieved through a deep contraction in imports due to output contraction rather than through an export boom. In response to capital inflows, output in developed countries is largely unaffected, while output in developing countries generally increases.

Based on the authors' main findings, it may be inappropriate to devalue the currencies of developing countries in order for these countries to achieve both high output growth and a strong balance of payments. The authors suggest that it may be more important for developing countries to improve their financial markets creating conditions receptive to accelerating a loosening of capital controls. 